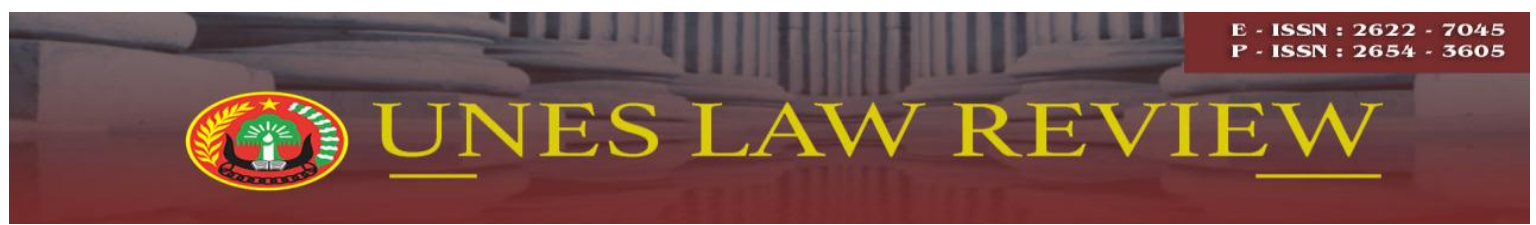

Email: uneslawreview@gmail.com

Online: http://review-unes.com/index.php/law

Volume 2, Issue 2, Desember 2019

\title{
MEMBANGUN BUDAYA ANTIKORUPSI DARI HAL TERKECIL SEJAK DINI
}

\author{
Aisyah Martanti Wulandhari \\ Politeknik Keuangan Negara STAN, Tangerang Selatan, Banten, Indonesia \\ E-mail : aisyahmw731@gmail.com
}

\begin{abstract}
Without us knowing, it turns out that Indonesia has been following quite a long time in globalization. There have been many changes that have occurred, starting from the cultural, political, economic system, transportation, lifestyle, especially in the field of technology, and many more. Globalization does have a good influence on Indonesia, but it cannot be denied, globalization also has a bad influence. We can see the culture of westernized life is already widespread among Indonesian people. One of them is selfishness and self harm and is detrimental to the interests of others. A concrete example of this is the act of corruption that seems to have been entrenched in Indonesia. And most of these acts of corruption are actually carried out by people who hold important positions of government, both from the legislative, executive, and judiciary institutions, where they should have received sufficiently higher education and have sufficiently understood that acts of corruption are acts of violation existing community laws and norms. Seeing the current condition of Indonesia, our nation needs future leaders who are free from corruption. Therefore, the nation's children are the hope of the next generation who will later hold the Indonesian government. This anti-corruption character is very good to be instilled in children at an early age of course they start from simple things. This article has been compiled with the aim of exploring ways to develop an anti-corruption culture, especially for Indonesian children at an early age. With the anti-corruption character that has been imprinted in itself since early, it is not impossible that Indonesia will be free from corruption in the future.
\end{abstract}

Kata Kunci: Korupsi, Budaya Antikorupsi, Usia Dini.

\section{PENDAHULUAN}

Kehadiran korupsi di Indonesia bukan lagi sesuatu yang mengejutkan. Indonesia sudah mengalami dan menghadapi begitu banyak kasus tindak pidana korupsi. Korupsi sangat merugikan negara dengan capaian angka yang tidak kecil. Korupsi sudah terjadi hampir di seluruh wilayah Indonesia. Para koruptor banyak berasal dari kalangan-kalangan yang tidak main-main. Kewenangan yang dipercayakan tidak dijalankan dengan penuh amanah dan tanggung jawab. Kurangnya komitmen dan kesadaran pribadi mengakibatkan tindak pidana korupsi begitu mudah terpikirkan, direncanakan, dibicarakan, hingga 
akhirnya disepakati dan dilakukan. Awal mula yang begitu sederhana, yaitu yang hanya berasal dari terlintasnnya 'satu hal' di pikiran, dapat berujung pada kerugian yang sangat besar. Tentu bukan hanya kerugian bagi satu pihak, tetapi juga bagi banyak pihak, bahkan bagi negara.

Menyelami lebih dalam, awal terjadinya korupsi timbul dari hati seseorang. Sifat mementingkan diri sendiri atau egoisme kerap menguasai diri para koruptor demi tercapainya kepentingan pribadi. Begitu juga dengan sifat serakah yang membuat ingin selalu lebih dan lebih, tidak pernah merasa cukup dengan apa yang sudah dimiliki. Selain itu, adanya celah-celah kesempatan juga membuat para koruptor merasa bahwa melakukan korupsi bukan menjadi masalah. Di atas semua itu, moral, iman, dan takwa yang tidak kuat, dapat mempermudah semakin terjatuhnya orang-orang dalam kasus ini.

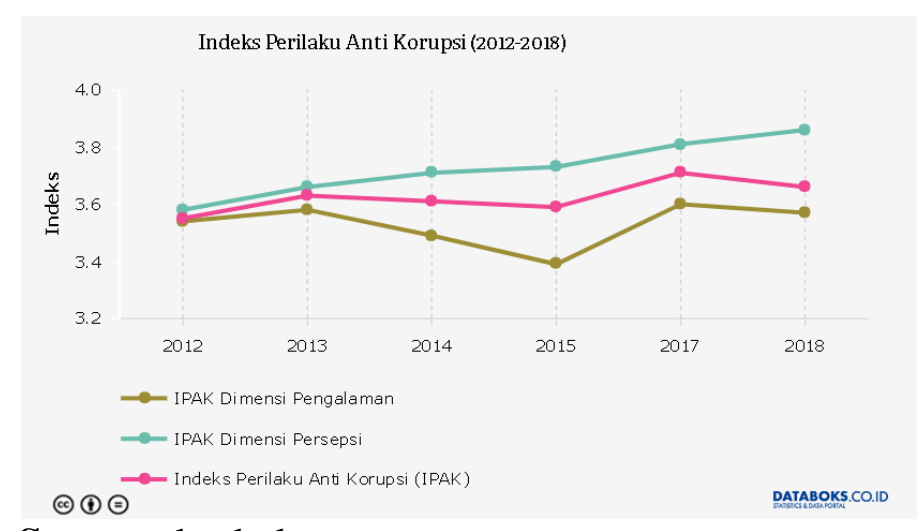

Source: databoks

Gambar 1. Indeks Perilaku Antikorupsi 2012-2018

Indeks Perilaku Anti Korupsi (IPAK) masyarakat Indonesia pada 2018 lebih rendah dari tahun sebelumnya. Data Badan Pusat Statistik (BPS) menunjukkan IPAK tahun ini berada di level 3,66 dari skala 0-5, tahun sebelumnya berada di 3,71. Semakin tinggi indeks mengindikasikan semakin tinggi perilaku masyarakat yang antikorupsi. Sebaliknya, semakin rendah indeks maka semakin rendah perilaku antikorupsi.

Indeks perilaku korupsi dari dimensi persepsi masyarakat pada tahun ini naik ke posisi 3,86 dari tahun sebelumnya. Sedangkan dari dimensi pengalaman mengalami penurunan menjadi 3,57 dari sebelumnya 3,6. Menurut Kepala BPS Suhariyanto, korupsi merupakan ancaman kriminal yang luarbiasa dan diperlukan pembekalan agar masyarakat menjadi sangat antikorupsi. 
Arus globalisasi di Indonesia begitu terasa membawa bangsa kita hingga sejauh ini. Banyak perubahan yang sangat signifikan terus berkembang dan menciptakan hal-hal baru yang membuat Indonesia menjadi lebih baik. Perkembangan yang paling terlihat adalah perkembangan teknologi, kemudian perkembangan terus merambah ke bidang infrastruktur, pendidikan, kesehatan, dan banyak lagi. Masyarakat pun menikmati perubahan yang ada dan mendapatkan lebih banyak kemudahan.

Ternyata ketika sisi positif sebuah perubahan itu ada, maka tak luput juga sisi negatifnya mengikuti. Di tengah kehidupan masyarakat, mulai muncul sifat antisosial. Setiap orang hanya sibuk memerhatikan dirinya dan tidak peduli dengan hal-hal lain di sekitarnya. Selain itu, dampak negatif globalisasi lainnya adalah ketika banyak orang mulai melupakan nilai-nilai kehidupan yang telah murni tertanam sejak bangsa ini ada.

Indonesia merupakan negara yang kaya akan budaya, baik alam maupun masyarakatnya. Keberagaman ini menjadikan Indonesia sebagai negara yang majemuk. Bermacam-macam penduduk dengan adat dan budayanya masing-masing tersebar di Indonesia. Budaya yang memberikan ajaran baik untuk setiap penduduk secara turuntemurun. Inilah yang mulai luntur akibat ketidaksiapan masyarakat untuk memertahankan budaya luhur bangsa kita di tengah era globalisasi. Berkaitan dengan maraknya kasus korupsi di Indonesia, budaya masyarakat Indonesia yang luhur inilah yang seharusnya dapat membentengi diri setiap orang untuk melakukan perbuatan yang luhur pula.

Tidak harus memulai dari sesuatu yang besar, karena justru segala sesuatu dimulai dari hal terkecil yang paling sederhana. Begitu juga dengan membangun budaya antikorupsi di zaman sekarang, di mana masyarakat sudah tak melirik lagi untuk mempunyai jiwa antikorupsi. Namun, tidak ada kata terlambat untuk memulai sebuah perubahan ke arah yang lebih baik. Mungkin kita memang tidak bisa mengubah masa lalu. Ya, kita tidak bisa membuat para koruptor membatalkan perbuatan tindak korupsinya karena memang sudah terjadi. Maka dari itu, ini waktunya untuk membangun kembali sebuah budaya antikorupsi kepada generasi-generasi baru penerus bangsa, yaitu anak-anak. Cukup memulai dari hal terkecil. Sebab, ketika benih antikorupsi sudah betul-betul tertanam dan diperlihara dengan baik pada diri seseorang sejak dini, maka benih itu akan bertumbuh dan menghasilkan buah dalam pemikiran, perkataan, dan perbuatan yang anti terhadap korupsi. 
Berdasarkan data yang diperoleh di bawah ini, ternyata angka kelahiran di Indonesia mengalami penurunan. Berikut ini kami sampaikan data yang mewakili.

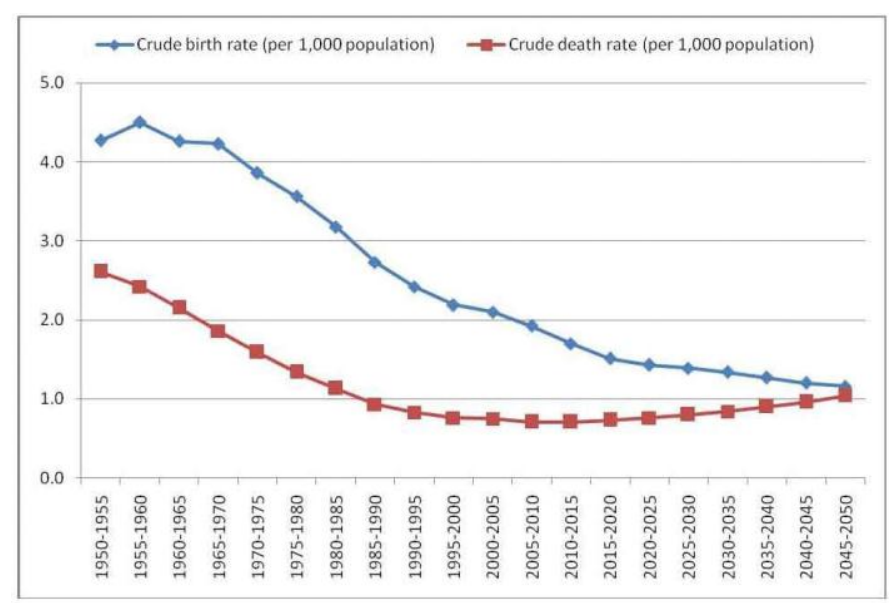

Source: Seri Kependudukan

Gambar 2. Grafik Angka Kelahiran dan Kematian di Indonesia

Grafik di bawah ini menunjukkan, bahwa menurunnya jumlah peserta didik dari Sekolah Dasar (SD) ke Sekolah Menengah Atas/Kejuruan (SMA/K). Hal ini berarti tidak semua anak di Indonesia dapat melanjutkan pendidikan mereka ke jenjang yang lebih tinggi. Ilmu dan pengetahuan yang didapat pun tidak dapat berkembang sebagaimana mestinya. Padahal, selain materi pelajaran, sekolah juga memberikan pendidikan karakter untuk membangun nilai-nilai budaya bangsa dalam diri peserta didik supaya tidak luntur.

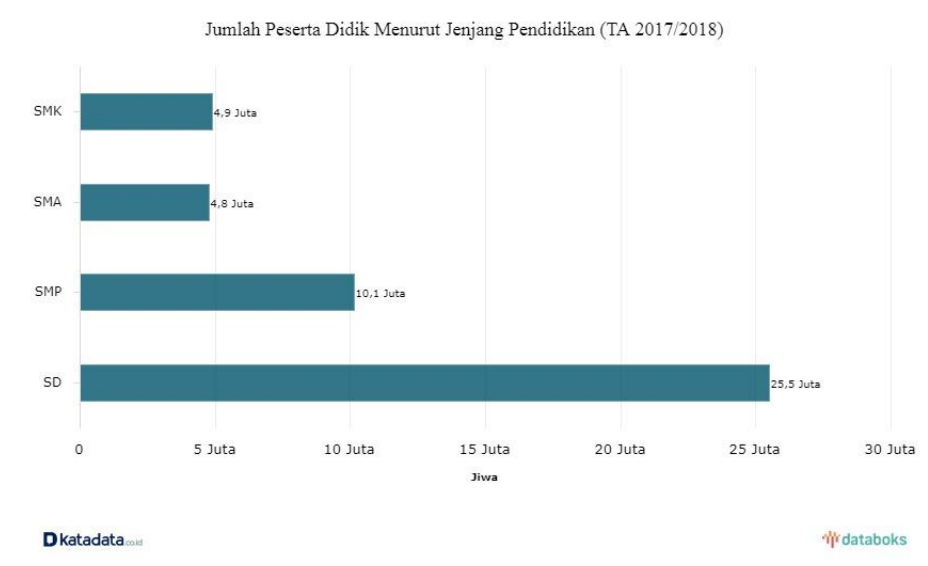

Source: databoks

Gambar 3. Jumlah Peserta Didik Menurut Jenjang Pendidikan (TA/2017/2018)

Berdasarkan Gambar 2., angka kelahiran di Indonesia menurun, tetapi pada Chart 3. ternyata anak-anak pelajar usia dini juga sama saja mengalami penurunan dalam arti tidak dapat meneruskan pendidikan ke tingkat selanjutnya. Seharusnya, dengan jumlah anak usia 
dini yang lebih sedikit, pemerintah bisa menyalurkan bantuan pendidikan lebih lagi supaya lebih banyak anak yang dapat bersekolah dan mendapat pendidikan yang baik dan benar. Padahal, setiap anak berhak mendapatkan pendidikan, baik secara materi maupun secara moral. Di masa depan, generasi muda inilah yang akan memegang pemerintahan bangsa Indonesia. Oleh karena itu, karakter yang berintegritas dapat mulai dibangun sejak usia dini, bahkan melalui hal-hal terkecil sekalipun.

Melalui latar belakang di atas, tujuan dari penelitian ini adalah untuk menjelaskan pentingnya membangun budaya antikorupsi melalui hal-hal terkecil sejak dini.

\section{METODE PENELITIAN}

\section{Sumber Data}

Sumber data merupakan bagian yang sangat penting dari suatu penelitian, karena sumber data berpengaruh langsung terhadap kualitas penelitian. Sumber data yang digunakan adalah sumber data primer. Data primer adalah data yang diperoleh langsung dari subjek penelitian, dalam hal ini peneliti memperoleh data atau informasi langsung dengan instrument-instrumen yang telah ditetapkan, Wahyu Purhantara, (2010: 79).

\section{Analisis Data}

Dalam penelitian ini, penulis menganalisis data menggunakan model Miles and Huberman. Analisis data dalam penelitian kualitatif dilakukan pada saat pengumpulan data berlangsung, dan setelah selesai pengumpulan data dalam periode tertentu. Miles and Huberman (1984) dalam Sugiyono (2012: 430) mengemukakan bahwa aktifitas dalam analisis data kualitatif dilakukan secara interaktif dan berlangsung secara terus menerus sampai tuntas sehingga datanya sudah jenuh. Analisis data yang digunakan yaitu menggunakan model interaksi menurut Miles and Huberman (1992) dalam Luqman Hakim (2007) sebagaimana gambar berikut:

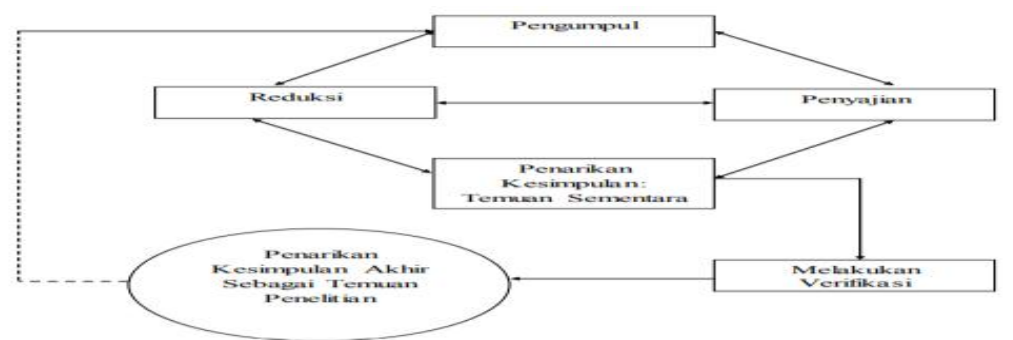

Sumber: Miles and Huberman (1992) dalam Luqman Hakim (2007)

Gambar 4. Model Interaksi Analisis Data 
1. Reduksi Data Setelah memperoleh data dari penelitian di lapangan, peneliti harus memilih data yang benar-benar akan digunakan, hal ini disebabkan data yang diperoleh di lapangan tentu sangat banyak dan tidak semua data yang diperoleh merupakan data yang dibutuhkan. Mereduksi data berarti merangkum, memilih hal-hal yang pokok, memfokuskan pada hal-hal yang penting, dicari tema dan polanya dan membuang yang tidak perlu. Dengan demikian data yang telah direduksi akan memberikan gambaran yang lebih jelas, dan mempermudah peneliti untuk melakukan pengumpulan data selanjutnya, dan mencarinya bila diperlukan. Dalam mereduksi data, peneliti akan memfokuskan pada hasil wawancara yang masuk pada kode yang telah ditetapkan seperti pengendalian internal, pemisahan fungsi, otorisasi, dan kewajaran aset.

2. Penyajian Data Miles and Huberman (1984) dalam Sugiyono (2012: 434) menyatakan "the most frequent form of display data for qualitative research data in the past has been narrative text". Artinya yang paling sering digunakan untuk menyajikan data dalam penelitian kualitatif adalah teks yang bersifat naratif. Selain itu, penyajian data berupa bagan, flowchart, tabel ataupun grafik akan peneliti sajikan apabila diperlukan dalam proses penyajian data. Jika ternyata data yang disajikan telah teruji kebenarannya dan telah sesuai, maka dapat dilanjutkan pada tahap penarikan kesimpulan. Namun, jika ternyata data yang disajikan belum sesuai dan belum dapat ditarik kesimpulan, maka dilakukan reduksi kembali bahkan tidak menutup kemungkinan untuk menjaring data baru. Dalam penelitian ini, data akan disajikan sesuai dengan rumusan masalah dengan tujuan memudahkan pembaca dalam mengidentifikasi hasil penelitian ini.

3. Penarikan Kesimpulan Sementara Sejak awal proses pengumpulan data di lapangan peneliti dimungkinkan untuk menarik kesimpulan. Pada saat peneliti member arti atau memaknai data-data yang diperoleh baik melalui observasi ataupun hasil wawancara berarti peneliti telah menarik kesimpulan. Kesimpulan awal yang dikemukakan masih bersifat sementara, dan akan berubah bila tidak ditemukan bukti-bukti yang kuat yang mendukung pada tahap pengumpulan data berikutnya.

4. Melakukan Verifikasi Setelah dilakukam reduksi data secara berulang dan diperoleh kesesuai dengan penyajian data, kemudian kesimpulan-kesimpulan sementara disempurnakan melalui verifikasi, maka dapat ditarik kesimpulan akhir yang merupakan temuan-temuan penelitian. Verifikasi data ini dilakukan dengan pengujian kredibilitas data yang akan dijelaskan lebih lanjut pada subbab berikutnya.

5. Penarikan Kesimpulan Akhir Sebagai Temuan Penelitian Setelah temuan-temuan sementara dilakukan verifikasi melalui teknikteknik pengecekan keabsahan temuan penelitian, selanjutnya dirumuskan simpulan temuan-temuan yang merupakan hasilhasil penelitian, kemudian diabstraksikan ke dalam proposisi-proposisi. Apabila kesimpulan yang dikemukakan pada tahap awal didukung oleh bukti-bukti yang valid dan konsisten saat peneliti kembali ke lapangan mengumpulkan data, maka kesimpulan yang dikemukakan merupakan kesimpulan yang kredibel (Sugiyono, 2011: 345). 
Namun apabila temuan penelitian ini dirasa belum cukup kredibilitas, dapat dilakukan perpanjangan pengamatan, wawancara lagi dengan sumber yang pernah ditemui maupun sumber yang baru.

\section{HASIL PENELITIAN DAN PEMBAHASAN}

Anak usia dini merupakan generasi harapan bangsa untuk masa depan Indonesia. Segala hal yang akan mereka lakukan pada saat beranjak dewasa merupakan cerminan dari apa yang mereka dapatkan saat kecil. Pada akhirnya, pembinaan anak usia dini sangat berpengaruh pada masa depan anak dan juga masa depan bangsa yang akan dipegang oleh mereka nantinya. Oleh sebab itulah sangat penting untuk menanamkan budaya anti korupsi kepada anak-anak usia dini. Tak harus melalui hal-hal yang rumit. Anak kecil dapat belajar budaya anti korupsi mulai dari hal yang terkecil sejak dini. Berikut ini penjelasan bagaiamana dan darimana saja anak-anak dapat belajar budaya anti korupsi di Indonesia:

\section{Peran Keluarga dalam Menumbuhkan Budaya Antikorupsi}

Definisi keluarga terdiri atas keluarga inti (yang terdiri dari ayah, ibu, dan anak) serta keluarga besar (yang terdiri dari keluarga inti ditambah dengan anggota keluarga lainnya seperti kakek dan nenek). Keluarga menjadi lembaga pendidikan pertama yang bersifat informal yang didapatkan oleh setiap anak. Dengan kata lain keluarga merupakan sekolah pertama semenjak seseorang dilahirkan, dan sangat berperan dalam pembentukan akhlak. Orang tualah yang memiliki peran utama dalam mendidik serta memperkenalkan prinsip kebaikan, kebenaran, dan kesalehan hidup. Hal ini berarti bahwa peran keluarga sangatlah besar di dalam mencetak generasi penerus sebuah bangsa. Dengan demikian keluarga turut andil di dalam memberi warna budaya sebuah bangsa, termasuk di dalamnya adalah menciptakan budaya antikorupsi. Sedangkan lembaga pendidikan laiinya adalah lembaga pendidikan formal, meliputi SD, SMP, SMA, sampai dengan Perguruan Tinggi, serta pendidikan nonformal, yang terdiri atas pelatihanpelatihan dan kursus keterampilan.

Segala perilaku manusia itu dibentuk karena faktor dari dalam diri, yaitu oleh kondisi atau kehendak manusia itu sendiri dan adanya pengaruh dari faktor dari luar diri, seperti faktor lingkungan dan keluarga. Oleh karena itu, teladan berperilaku yang baik dari 
lingkungan sekitar, terutama keluarga akan berpengaruh besar terhadap pola pikir anak di kemudian hari dan pada akhirnya akan membentuk karakter si anak sendiri.

Dalam sebuah lingkungan keluarga, anak akan melakukan peniruan tingkah laku yang dilakukan oleh orang-orang di sekitarnya. Oleh sebab itu teladan yang baik dari seluruh anggota keluarga seperti ketaatan ber-ibadah, bertutur kata yang baik, berperilaku sopan sesuai dengan budaya bangsa, jujur dalam berkata dan bertindak sangatlah penting ditanamkan sejak usia dini, sebab anak (usia 3-5 tahun) merupakan peniru yang ulung. Karenanya perilaku antikorupsi tersebut tidak dapat tertanam dalam diri anak apabila hanya diajarkan, jadi harus dicontohkan.

Berikut merupakan nilai-nilai antikorupsi yang perlu ditanamkan dalam diri anak sejak usia dini yang dapat dikenalkan dari lingkungan keluarga:

1. Jujur

Jujur di sini berarti mengatakan apapun dan berbuat sesuai dengan faktanya. Atau lebih mudahnya, sering dikatakan bahwa jujur itu adalah tidak berbohong, tidak melakukan perbuatan curang, dan tidak mengakui milik orang lain sebagai milik diri sendiri.

2. Disiplin

Yaitu berkomitmen untuk selalu berperilaku konsisten dan berpegang teguh pada aturan yang ada dalam semua kegiatan

3. Tanggung Jawab

Yaitu selalu menyelesaikan pekerjaan atau tugas-tugas secara tuntas dengan hasil terbaik, serta berani menanggung semua perbuatan yang telah dilakukan.

4. Kerja Keras

Yaitu selalu berupaya untuk menuntaskan suatu pekerjaan dengan hasil yang terbaik, melakukannya dengan penuh kesungguhan, serta menghindari perilaku instan atau jalan pintas yang mengarah pada kecurangan.

5. Prinsip kesederhanaan

Yaitu selalu berpenampilan apa adanya, tidak berlebihan, tidak pamer dan tidak ria. 


\section{Mandiri}

Yaitu selalu menuntaskan pekerjaan tanpa mengandalkan bantuan dari orang lain, tidak menyuruh atau menggunakan kewenangannya untuk menyuruh orang lain untuk sesuatu yang mampu dikerjakan sendiri, berusaha menyelelsaikan permasalahannya sendiri tanpa melibatkan orang lain.

7. Adil

Yaitu selalu menghargai perbedaan dan tidak pilih kasih, karena sebagai seorang manusia kita memiliki hak yang sama baik di mata hukum maupun di mata Tuhan.

8. Keberanian

Keberanian dapat dilatih dengan selalu berbuat jujur, berani menolak ajakan untuk berbuat curang, berani melaporkan adanya kecurangan, dan berani mengakui kesalahan yang telah diperbuat.

9. Menumbuhkan rasa kepedulian

Yaitu senantiasa menjaga diri dan lingkungan agar tetap konsisten dengan aturan yang berlaku, serta selalu berusaha untuk menjadi teladan dalam menegakkan disiplin, kejujuran, dan tanggung jawab.

\section{Melalui Budaya Sekolah}

Budaya sekolah yang dimanifestasikan melalui perilaku warga sekolah, kantin kejujuran, kedisiplinan, dan tanggung jawab diduga mendukung pelaksanaan pendidikan antikorupsi yang dijabarkan sebagai berikut :

1. Perilaku warga sekolah

Di sini, setiap warga sekolah berperan dalam memandu pola sikap dan perilaku murid dengan secara bertahap, mengurangi pengawasan, dan meningkatkan kesadaran diri akan pentingnya sikap dan perilaku yang benar dan cerdas, membiasakan untuk bekerja dengan baik dan menanamkan rasa bangga ketika pekerjaannya tercapai, serta memberikan perasaan bersedia bekerjasama dengan orang lain.

Selain itu, bertindak adil, sportif, jujur, benar, dan lain-lain yang diukur sesuai dengan standar moral tinggi, membiasakan bertindak dengan sopan santun dan dengan tata krama yang baik, ceria kepada orang lain, dan mengapresiasi layanan yang diterima 
dari orang lain, berkebiasaan bertindak berani dalam membela yang benar, dan bertindak rendah hati terhadap yang lebih muda dan lemah, serta kebiasaan hidup sehat, juga perlu diterapkan dalam lingkungan sekolah.

2. Kantin kejujuran

Kantin kejujuran adalah kantin yang menjual makanan kecil dan minuman. Kantin kejujuran tidak memiliki penjual dan tidak dijaga. Makanan atau minuman dipajang dalam kantin. Dalam kantin tersedia kotak uang, yang berguna menampung pembayaran dari yang membeli makanan atau minuman. Bila ada kembalian, pengunjung/pegawai mengambil dan menghitung sendiri uang kembalian dari dalam kotak tersebut. Kantin kejujuran merupakan salah satu bentuk kegiatan dalam pendidikan antikorupsi.

3. Kedisiplinan dan tanggung jawab

Disiplin ialah ketaatan atau kepatuhan kepada peraturan. Sebaliknya untuk mengatur kehidupan manusia memerlukan hidup yang disiplin. Manfaat dari disiplin ialah seseorang dapat mencpai tujuan dengan waktu yang lebih efisien. Kedisiplinan memiliki dampak yang sama dngan nilai-nilai antikorupsi lainnya yaitu dapat menumbuhkan kepercayaan dari orang lain dalam berbagai hal. Kedisiplinan dapat diwujudkan antara lain dalam bentuk kemampuan mengatur waktu dengan baik, kepatuhan kepada seluruh peraturan dan ketentuan yang berlaku, mengerjakan segala sesuatu dengan tepat waktu, dan fokus pada pekerjaan, sedangkan tanggung jawab adalah keadaan wajib menanggung segala sesuatunya (kalau terjadi apa-apa boleh dituntut, dipersalahkan dan diperkarakan). Seseorang yang memiliki tanggung jawab akan memiliki kecenderungan menyelesaikan tugas dengan lebih baik.

4. Peran guru dalam menunjukkan sikap antikorupsi

Guru merupakan teladan siswa untuk berbuat. Jika guru dapat mencerminkan sikap anti korupsi, niscaya siswa-siswanya dapat mempelajari dan mengikuti hal yang dicerminkan guru tersebut. Memang sulit bagi guru untuk mencerminkan tindakan yang baik kepada murid-muridnya. Namun setidaknya guru dapat menjadi teladan bagi siswanya, menjaga perilaku tidak hanya di depan siswa tetapi juga di lingkungan mana pun ia berada, bukan hanya di lingkungan sekolah. Adapun yang bisa dilakukan guru adalah sebagai berikut: 
a. Melalui keteladanan

Ini yang berat bagi seorang guru. Memberi contoh. Sifat anak adalah suka meniru, oleh karena itu sebagai guru hendaknya harus selalu memberi contoh yang baik sesuai dengan norma dan aturan yang ada. Maksud membericontoh disini bukan sekedar menjelaskan contoh perilaku anti korupsi, tetapi ia sendiri mengamalkan perilaku yang ia ajarkan,sehingga dapat dicontoh para siswa. Seperti halnya sikap jujur, tidak berbohong, dan memakan apa yang bukan haknya. Merujuk pada nasihat Bapak Pendidikan Indonesia Ki Hajar Dewantara, sekolah dan guru yang tidak bisa memberikan contoh keteladanan (ing ngarso sung tulodho) maka akan menyebabkan siswa mendapatkan bahaya dan kecelakaan (nyaru beboyo lan ciloko) pada kemudian harinya.

b. Melalui pembiasaan

Pembiasaan adalah merupakan salah satu cara yang dapat dipergunakan untuk mendidik siswa. Dengan cara ini diharapkan siswa akan terbiasa melalukan hal yang baik-baik. Contoh untuk menanamkan jiwa anti korupsi ialah dengan jujur, seperti diadakannya kantin kejujuran dalam sekolah, disitulah siswa dilatih untuk bersikap jujur, karena ia yang mengambil jajan, ia yang membayar, ia yang menghitung dan ia juga yang memberikan kembalian uang sisa jajan.

c. Peningkatan ketaqwaan

Ditekankan pada siswa untuk sholat dhuhur secara berjamaah bersama guruguru saat istirahat kedua. Untuk itulah sekolah harus mengkondisikan agar siswa mempunyai waktu lebih banyak untuk persiapan sholat sampai dengan pelaksanaan sholat, kemudian dilanjutkan istirahat siswa. Misalnya jam istirahat kedua diberikan waktu ishoma selama 20 menit, hal tersebut melebihi jam istirahat pertama yang hanya 10 menit.

d. Lomba dan narasumber

Lomba-lomba antar kelas maupun individu yang bertema anti korupsi, diantaranya lomba pidato, melawak, membuat serta membacakan puisi anti korupsi, poster-poster anti korupsi, karikatur anti korupsi, dan cerpen anti korups. Mengundang narasumber dari: kepolisian, KPK, kejaksaan, kehakiman, ulama yang dapat memberikan wawasan dan memotivasi siswa untuk bersikap anti korupsi di segala bidang kehidupan

e. Penerapan reward dan punishment secara tegas

Dalam kegiatan belajar, motivasi sangat diperlukan. Motivasi adalah dorongan untuk mencapai tujuan tertentu. Dorongan itu bisa saja berbentuk antusiasme, harapan dan semangat. Salah satu contoh dalam menumbuhkan motivasi, metode reward dan punishment seringkali digunakan oleh para guru atupun orang tua. Reward \& punishment merupakan teori psikologi tentang belajar. Reward secara bahasa berarti hadiah dan punishment berarti hukuman. Dalam hal ini teori reward \& punishment dapat diaplikasikan dalam mendidik seseorang. Contohnya apabila 
seorang anak mendapatkan peringkat dikelasnya maka ia akan diberi reward, tapi kalau ia berbuat nakal maka ia akan diberi punishment.

5. Strategi dan implementasi pendidikan antikorupsi di lingkungan sekolah

Berikut merupakan beberapa cara yang dapat dilakukan oleh para penanggung jawab anak dalam lingkungan sekolah untuk menumbuhkan budaya atikorupsi:

a. Memprogramkan pendidikan antikorupsi di sekolah melalui program kegiatan intra, ekstra, dan kokurikuler serta disiplin sekolah.

b. Sekolah diberi keleluasaan untuk merencanakan, melaksanakan, dan mengevaluasi pendidikan antikorupsi.

c. Pengoptimalan fungsi kegiatan rekreatif untuk praktik pendidikan antikorupsi. Kegiatan kesenian, olahraga, susastra, dan berbagai kegiatan yang sifatnya rekreatif seharusnya bisa dioptimalkan sebagai wahana implementasi pendidikan antikorupsi bagi anak sekolah.

d. Internal capacity building di kalangan guru dan kepala sekolah untuk dapat menyusun action plan implementasi pendidikan antikorupsi secara terintegrasi antarlintas mata pelajaran serta melatih mereka dalam mengembangkan berbagai model pembelajaran dan model penilaian serta pengukuran pencapaian pendidikan antikorupsi siswa-siswinya.

e. Merancang sistem yang dapat menciptakan keteladanan di tingkat sekolah dan orangtua serta para tokoh masyarakat. Masing-masing pihak harus punya action plan yang jelas, disertai dengan sistem monitoring dan evaluasi secara berkala yang memungkinkan untuk menjamin sustanabilitas penyelenggaraan pendidikan antikorupsi.

Analisis artikel "Membangun Budaya Antikorupsi dari Hal Terkecil Sejak Usia

Dini” ini sejalan atau mendukung artikel-artikel sebelumnya, diantaranya:

1. Agus Mulya Karsona (2011:23)

2. Hartati (2005)

3. Jamiah (2010)

\section{PENUTUP}

Tak hanya orang dewasa, anak-anak usia dini juga dapat berperan dalam membentuk negara yang bersih dari korupsi. Dengan pendidikan dan kebiasaan yang diterapkan di sekolah-sekolah, juga hal-hal kecil yang dapat membangun jiwa anak-anak yang semakin sadar dan mengerti betapa berbahaya dan menjijikkannya perbuatan korupsi itu sendiri. Dari diskusi yang telah penulis lakukan juga penulis berharap pembaca dapat memberikan contoh yang baik kepada anak-anak yang masih belum mengerti arti penting dan tanggung jawab mereka kedepannya. Anak-anak merupakan generasi harapan bangsa yang akan membawa bangsa Indonesia menjadi lebih baik jika mereka dapat menanamkan 
budaya anti korupsi dalam jiwa dan ruh mereka masing-masing. Penulis juga berharap anak-anak dapat berperan dalam perayaan Hari Anti Korupsi, setidaknya mereka mengerti keadaan dan kondisi Indonesia saat ini sehingga timbul keinginan dalam jiwa mereka untuk mengubah bangsa Indonesia menjadi lebih baik lagi.

Dengan begitu, akan lebih banyak jiwa yang sadar akan pentingnya menanamkan budaya anti korupsi. Jika nantinya anak-anak sudah paham dan mengerti arti didikan budaya anti korupsi bagi mereka, orang dewasa niscaya akan malu jika berbuat korupsi dalam lingkungan mereka. Hal ini juga berpengaruh positf dalam pembangunan karakter jiwa bangsa kedepannya. Penulis berharap pembelajaran anti korupsi dapat disebarluaskan ke berbagai sekolah-sekolah dasar yang belum menerapkannya. Bagi yang sudah menerapkannya, penulis berharap pendidikan anti korupsi dapat dimodifikasi sedemikian rupa sehingga lebih menyenangkan untuk dipelajari oleh anak bangsa. dengan metode pembelajaran yang tidak biasa, diharapkan menumbuhkan semangat keingintahuan anakanak bangsa sehingga mereka dapat berpikir kreatif dan inovatif dalam membangun bangsa yang bersih dari korupsi. Memang hamper mustahil melihat Indonesia yang bersih dari korupsi. Namun, bersama kita bisa mencegah dan mengurangi angka tindak pidana korupsi di Indonesia dengan mencerdaskan kehidupan bangsa di mulai dari anak-anak usia dini yang merupakan generasi harapan bangsa.

\section{DAFTAR PUSTAKA}

\section{Buku Teks :}

Gunawan, Imam. 2013. Metode Penelitian Kualitatif. Jakarta: Bumi Aksara.

Sukmadinata, S. N. 2005. Metode Penelitian. Bandung: PT Remaja Rosdakarya.

Aisyah, S., Amini, M., Chandrawati, T., \& Novita, D. (2014). Pengembangan dan konsep dasar perkembangan anak usia dini.

APRILIA, A. E. (2019). RELEVANSI PIDATO SOEKARNO 1 JUNI 1945 BAGI PENGARUH GLOBALISASI PADA NILAI-NILAI GOTONG ROYONG.

Sulastri, I. (2012). Perlunya Menanamkan Budaya Antikorupsi Dalam Diri Anak Sejak Usia Dini. Mimbar Hukum - Fakultas Hukum Universitas Gadjah Mada, 24(1), 98-109.

\section{Web \& Jurnal Karya Imiah}

Chairiyah, C., Nadziroh, N., \&Pratomo, W. (2017). Konsep Pembelajaran Pkn dalam Menanamkan Pendidikan Anti Korupsi Sejak Dini Di sekolah Dasar. TAMAN CENDEKIA: Jurnal Pendidikan Ke-SD-an, 1(1), 1-8. 
Ekawati, P. L., Falani, A. Z., Kom, S., \& Kom, M. (2015). Pemanfaatan Teknologi Game Untuk Pembelajaran Mengenal Ragam Budaya Indonesia Berbasis Android. Jurnal Link, 22(1), 30-36.

Montessori, M. (2012). Pendidikan antikorupsi sebagai Pendidikan karakter di sekolah. Jurnal Demokrasi, 11(1).

Rahmawati, Y. (2012). Pengenalan Budaya Melalui Bercerita untuk Anak Usia Dini. Jurnal Pendidikan Anak, 1(1).

Sakinah, N., \&Bakhtiar, N. (2019). Model Pendidikan Anti Korupsi di Sekolah Dasar dalam Mewujudkan Generasi Yang Bersih dan Berintegritas Sejak Dini. elIbtidaiy: Journal of Primary Education, 2(1), 39-49

Widyastuti, W. W., \& Rosyada, A. (2017). Kearifan Lokal sebagai Bingkai Internalisasi Nilai-Nilai Nasionalisme dalam Era Globalisasi. In Seminar Nasional PKn UNNES (Vol. 1, No. 1, pp. 104-110).

Adityo AlBarwa. 2014. Analisis Pengujian Pengendalian Internal Untuk Menilai Kewajaran Aset (Audited). [Online] Tersedia http://repository.upi.edu/15413/6/S_PEA_1005426_Chapter3.pdf. [2014].

Wordpress. 2009. Seri Kependudukan (Audited). [Online] Tersedia https://serikependudukan.wordpress.com/tag/angka-kelahiran/. $\quad[28$ Oktober 2009]. 